\title{
Activity of $\mathrm{FeO}$ in the Ternary System $\mathrm{SiO}_{2}-\mathrm{MgO}-\mathrm{FeO}$ and Constitution of $\mathrm{SiO}_{2}{ }^{*}$
}

\section{By Mitsuhiro SAKAWA, ${ }^{* *}$ S. G. WHITEWAY ${ }^{* * *}$ and C.R. MASSON ${ }^{* * *}$}

\section{Synopsis}

Activity of $\mathrm{FeO}$ in the ternary system $\mathrm{MgO}-\mathrm{SiO}_{2}-\mathrm{FeO}$ was measured by means of the levitation method of an induction furnace.

Activity of $\mathrm{MgO}$ in the binary system $\mathrm{MgO}-\mathrm{SiO}_{2}$ was calculated from the activity of $\mathrm{FeO}$ in this ternary system $\mathrm{MgO}-\mathrm{SiO}_{2}-\mathrm{FeO}$.

Theoretical expressions derived for molecular size distributions in multichain polymers (polymer theory) were applied to this binary system $\mathrm{MgO}$ $\mathrm{SiO}_{2}$, and the theoretical curve from the polymer theory fitted the calculated values of activities of $\mathrm{MgO}$ in the system $\mathrm{MgO}-\mathrm{SiO}_{2}$, when the equilibrium constant of the polymer theory $\left(\mathrm{K}_{11}\right)$ is 0.01 .

Application of the polymer theory to the ternary system $\mathrm{MgO}-\mathrm{SiO}_{2}$ $\mathrm{FeO}$ seems to be possible with several assumptions.

\section{Introduction}

In a previous paper, ${ }^{1)}$ theoretical expressions were derived for the most probable distribution of molecular sizes in branched polymers formed by the selfcondensation of a multi-functional monomer.

Authors applied this theory to the calculation of activities in binary silicate melts. ${ }^{2}$ ) But the acivity of $\mathrm{MgO}$ in $\mathrm{SiO}_{2}-\mathrm{MgO}$ is not yet measured, because this system has high melting point in temperature. In this paper the activity of $\mathrm{FeO}$ in $\mathrm{FeO}-\mathrm{SiO}_{2}-\mathrm{MgO}$ ternary system was measured, using this result, the activity of $\mathrm{MgO}$ in $\mathrm{MgO}-\mathrm{SiO}_{2}$ binary system was calculated, then was applied to the polymer theory. An attempt has been made to apply the polymer theory to the activity of $\mathrm{FeO}-\mathrm{MgO}-\mathrm{SiO}_{2}$ ternary system.

\section{Experimental}

\section{Materials}

High-purity iron, designated AGL 20, was supplied by British Steel Corporation. Impurities apart from oxygen, were reported to be less than $0.05 \%$. The oxygen and nitrogen impurities were 0.0971 and $0.0024 \%$ respectively by the vacuum analysis. $\mathrm{FeO}$ was prepared from the high-purity iron and $\mathrm{Fe}_{2} \mathrm{O}_{3}$ (Anachemica Chemicals).

Magnesium silicates with various molar ratios of $\mathrm{MgO} / \mathrm{SiO}_{2}$ were prepared from $\mathrm{MgO}$ (BDH Chemicals Ltd.) and $\mathrm{SiO}_{2}$ (Mallinckrodt, AR) by sintering at $900^{\circ} \mathrm{C}$ for $4 \mathrm{hr}$.

Argon (Canada Liquid Air Co., Ltd.) was passed through titanium turnings at $880^{\circ} \mathrm{C}$.

Helium (Airco) was used without purification.

\section{Apparatus and Procedure}

The levitation apparatus was similar to that used by previous works. ${ }^{3)}$
A sample of metal to be levitated was machined to the form of a cylinder of approximately 0.2 inch in diameter, with a cavity drilled along the axis.

It weighed about $1.0 \mathrm{~g}$. A known weight of sintered magnesium silicate was inserted and a slightly tapered, tight-fitting stopper, machined from the same metal, was pressed into the cavity to encapsulate the oxide. The total weight of crucible and stopper was about $1.5 \mathrm{~g}$ and of magnesium silicate about $0.07 \mathrm{~g}$ in each experiment.

The procedure of levitation was described ${ }^{3)}$ previously. The sample of slag was obtained by quenching into water, and the sample of metal was obtained by vacuum suction.

\section{Results}

The activity of FeO was computed with the reference to the non-stoichiometric oxide in equilibrium with liquid iron as standard state. ${ }^{3)}$

$$
\log [\% \mathrm{O}]_{\mathrm{sat}}=-6329 / \mathrm{T}+2.734
$$

The activity of $\mathrm{FeO}$ in the ternary system of $\mathrm{SiO}_{2}$ $\mathrm{MgO}-\mathrm{FeO}$ is shown in Fig. 1.

\section{Discussion}

1. The Activity of $\mathrm{MgO}-\mathrm{FeO}$ System

The activity of $\mathrm{FeO}$ in the high $\mathrm{MgO}$ region was

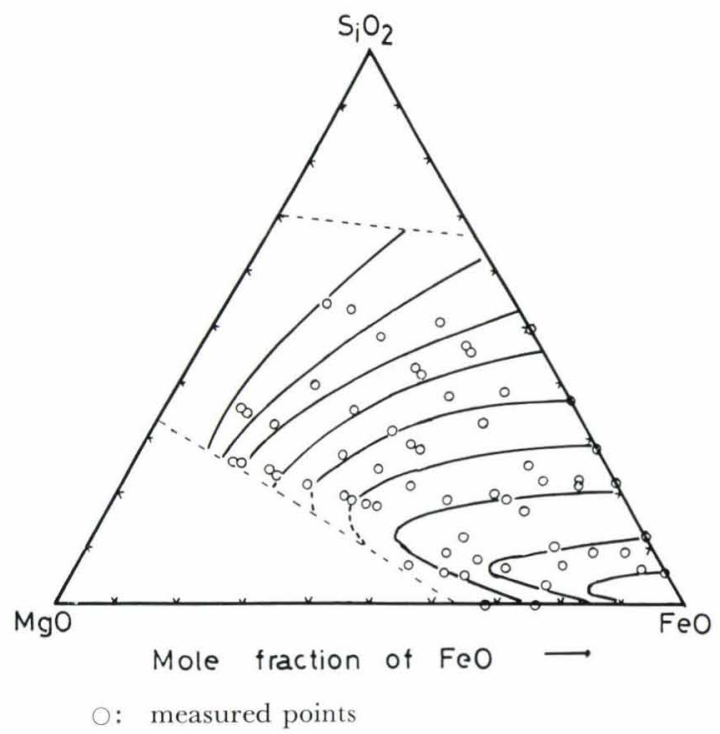

Fig. 1. Isoactivity lines of $\mathrm{FeO}$ at $1900^{\circ} \mathrm{C}$ in the $\mathrm{MgO}-$ $\mathrm{SiO}_{2}-\mathrm{FeO}$ system

* Originally published in Tetsu-to-Hagané, 62 (1976), 176, in Japanese. English version received May 13, 1977.

** Formerly a postdoctorate fellow at National Research Councile of Canada. Now at Fundamental Research Laboratories, Nippon Steel Corp., Ida, Nakahara-ku, Kawasaki 211.

*** Atlantic Regional Laboratory, National Research Council of Canada, Halifax, Nova Scotia, Canada. 
not obtained due to the high temperature of the melting point. So the activity of $\mathrm{FeO}$ in $\mathrm{MgO}-\mathrm{FeO}$ system may be calculated from the following methods.

Darken ${ }^{4}$ proposed a quadratic formalism that there is a linear relationship between the logarithm of the activity coefficient and mole fraction in both low and high mole fraction regions. If this relationship is applied to $\mathrm{MgO}-\mathrm{FeO}$ system, the activity coefficient of $\mathrm{FeO}$ in the high $\mathrm{MgO}$ region is obtained and then the activity of $\mathrm{FeO}$ in this region is calculated. The activity of $\mathrm{MgO}$ is obtained by the Darken's equation

$$
\ln \gamma_{\mathrm{MgO}}=-\alpha_{2} \mathcal{N}_{\mathrm{FeO}} \cdot \mathcal{N}_{\mathrm{MgO}}-\int_{N_{\mathrm{Mg} O=1}}^{N_{\mathrm{MgO}}} \alpha_{2} d\left(\mathcal{N}_{\mathrm{MgO}}\right) \ldots \ldots(1)
$$

where, $\quad \gamma_{\mathrm{Mgo}}$ : the activity coefficient of $\mathrm{MgO}$

$$
\begin{aligned}
& \alpha_{2}=\ln \gamma_{\mathrm{FeO}} / \mathcal{N}_{\mathrm{MgO}}^{2} \\
& \mathcal{N}_{\text {FeO }}, \mathcal{N}_{\text {Mgo }}: \text { mole fraction of } \mathrm{FeO} \text { and } \mathrm{MgO} \text {, } \\
& \text { respectively. }
\end{aligned}
$$

The activity of $\mathrm{MgO}$ is also calculated from the Gibbs-Duhem equation. Figure 2 shows a plot of $\mathcal{N}_{\text {Feo }}$ against the activities of $\mathrm{FeO}$ and $\mathrm{MgO}$ in the $\mathrm{FeO}-\mathrm{MgO}$ binary system.

2. The Activity of $\mathrm{MgO}$ in $\mathrm{MgO}-\mathrm{SiO}_{2}$ System and the Equilibrium Constant of the Reaction in $2 \mathrm{Mg}_{2} \mathrm{SiO}_{4}=$ $\mathrm{Mg}_{3} \mathrm{Si}_{2} \mathrm{O}_{7}+\mathrm{MgO}$

According to Darken ${ }^{5)}$ the activity of $\mathcal{N}_{1}-\mathcal{N}_{3}$ system can be calculated if the activities between $\mathcal{N}_{2}-\mathcal{N}_{1}, \mathcal{N}_{2}-$ $\mathcal{N}_{3}$ and $\mathcal{N}_{1}-\mathcal{N}_{2}-\mathcal{N}_{3}$ are known.

$$
\begin{aligned}
& F^{x s}=\left(1-\mathcal{N}_{2}\right)\left[\int_{1}^{N_{2}} \bar{F} x s /\left(1-\mathcal{N}_{2}\right)^{2} \cdot d \mathcal{N}_{2}\right]_{N_{1} / N_{3}} \\
& -\mathcal{N}_{1}\left[\int_{1}^{0} \bar{F}_{2}^{x s} /\left(1-\mathcal{N}_{2}\right)^{2} d \mathcal{N}_{2}\right]_{N_{3}=0} \\
& -\mathcal{N}_{3}\left[\int_{1}^{0} \bar{F}_{2}^{x_{s}} /\left(1-\mathcal{N}_{2}\right)^{2} d \mathcal{N}_{2}\right]_{N_{1}=0}
\end{aligned}
$$

where, $\quad F^{x s}$ : mixing excess molar free energy

$$
\bar{F}^{x s}=R T \ln \gamma_{2}: \quad \text { excess molar free energy }
$$

From the data of the activity in $\mathrm{MgO}-\mathrm{SiO}_{2}-\mathrm{FeO}$ system, authors found the relationship between $\ln \gamma_{\mathrm{FeO}} /\left(1-\mathcal{N}_{\mathrm{FeO}}\right)^{2}$ and $\mathcal{N}_{\mathrm{FeO}}$ to be a sixth power series within maximum error $3.6 \%$ in every ratio of $\mathcal{N}_{\mathrm{MgO}} / \mathcal{N}_{\mathrm{SiO}_{2}}$

$$
\begin{aligned}
\frac{\ln \gamma_{\mathrm{FeO}}}{\left(1-\mathcal{N}_{\mathrm{FeO}}\right)^{2}} & =\mathrm{A}+\mathrm{B} \mathcal{N}_{\mathrm{FeO}}+\mathrm{C} \mathcal{N}_{\mathrm{FeO}}^{2}+\mathrm{D} \mathcal{N}_{\mathrm{FeO}}^{3} \\
& +\mathrm{E} \mathcal{N}_{\mathrm{FeO}}^{4}+\mathrm{F} \mathcal{N}_{\mathrm{FeO}}^{5}+\mathrm{G} \mathcal{N}_{\mathrm{FeO}}^{6} \quad \ldots
\end{aligned}
$$

where $\mathrm{A}$ to $\mathrm{G}$ are coefficients.

By substituting for the calculated values in Eq. (2), the excess free energy of the $\mathrm{MgO}-\mathrm{SiO}_{2}$ system is calculated.

Figure 3 shows the excess free energy of $\mathrm{MgO}$ $\mathrm{SiO}_{2}$, compared with the excess free energy of $\mathrm{CaO}-$ $\mathrm{SiO}_{2}$ by Darken. $\left.{ }^{6}\right)$

$$
R T \ln \gamma_{\mathrm{MgO}}=F^{x s}+\left(1-\mathcal{N}_{\mathrm{MgO}}\right)\left(d F^{x s} / d \mathcal{N}_{\mathrm{MgO}}\right)
$$

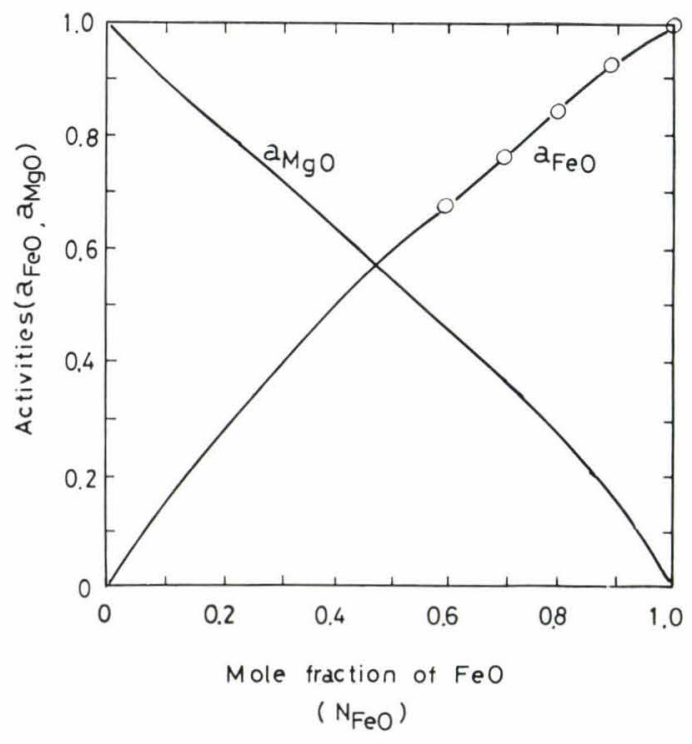

: measured points

The line of $a_{\mathrm{FeO}}$ is calculated values by the Darken's $\operatorname{method}^{41}$.

The line of $a_{\mathrm{MgO}}$ is calculated values from $a_{\mathrm{FeO}}$ by the Gibbs Duhen equation

Fig. 2. Activities of $\mathrm{FeO}$ and $\mathrm{MgO}$ for the system $\mathrm{FeO}-$ $\mathrm{MgO}$

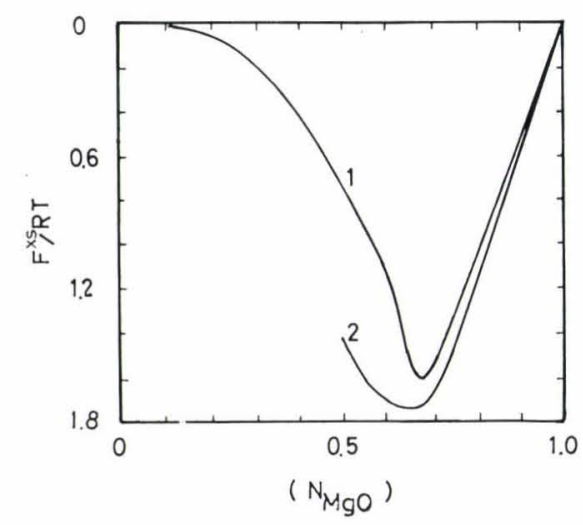

Fig. 3. Excess free energy chart for the system $\mathrm{MgO}-\mathrm{SiO}_{2}$ (1) at $1900^{\circ} \mathrm{C}$, compared with the system $\mathrm{CaO}$ $\mathrm{SiO},{ }^{6)}$ and $(2)$ at $1600^{\circ} \mathrm{C}$

Figure 4 shows the activity of $\mathrm{MgO}$ in the $\mathrm{MgO}$ $\mathrm{SiO}_{2}$ system from the results of Eq. (4), and the line is computed from the polymer theory ${ }^{1)}$ of $K=0.01$. Figure 5 shows the ion fractions of $\mathrm{SiO}_{4}{ }^{4-}, \mathrm{Si}_{2} \mathrm{O}_{7}{ }^{6-}$, $\mathrm{Si}_{3} \mathrm{O}_{10}{ }^{5-}, \mathrm{Si}_{4} \mathrm{O}_{13}{ }^{10-}$ and $\mathrm{Si}_{10} \mathrm{O}_{31}{ }^{22-}$ against mole fraction of $\mathrm{SiO}_{2}$ in the system $\mathrm{MgO}-\mathrm{SiO}_{2}$.

\section{Discussion about the Activity of the Ternary System}

If the equilibrium constant of reaction between $\mathrm{SiO}_{4}{ }^{4-}$ and $\mathrm{Si}_{2} \mathrm{O}_{7}{ }^{6-}$ is known in metal oxide- $\mathrm{SiO}_{2}$ binary system, the activity of the metal oxide is estimated by the polymer theory. ${ }^{1)}$ But this theory can not be applied to the ternary system, becuase the mole fraction of cation is not unity in all regions.

We may assume the following conditions in the ternary system.

(1) The equilibrium constant $\left(K_{11}\right)$ of the reaction $2 \mathrm{SiO}_{4}{ }^{4-} \rightleftarrows \mathrm{Si}_{2} \mathrm{O}_{7}{ }^{6-}+\mathrm{O}^{2-}$ in the polymer theory is constant for the given ratio of mole fraction of $\mathrm{MgO}$ 


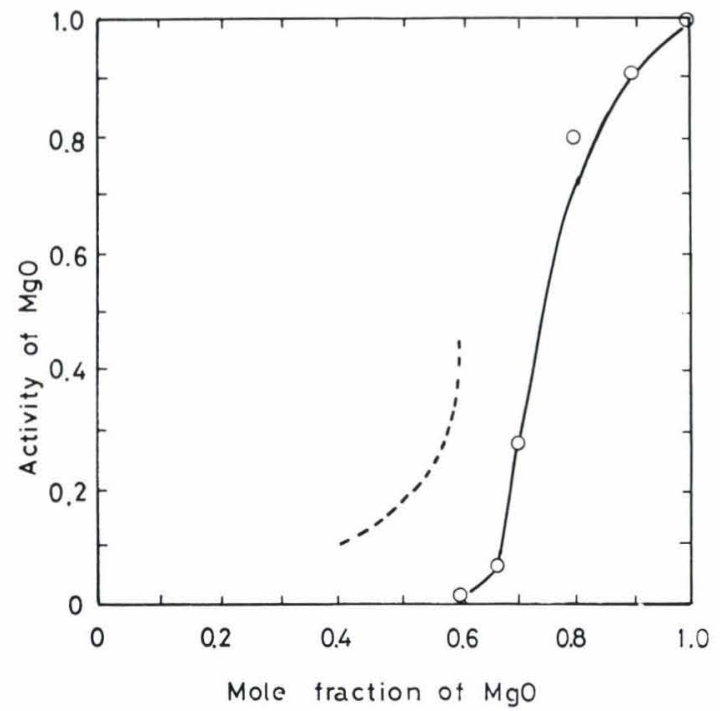

Circles are from excess molar free energies of mixing (Fig. 3).

The line is calculated from the polymer theory with $\mathrm{K}_{11}=0.01$.

The broken line is after J. F. Elliott ${ }^{7)}\left(1600^{\circ} \mathrm{C}\right)$.

Fig. 4. Activity of $\mathrm{MgO}$ plotted against mole fraction of $\mathrm{MgO}-\mathrm{SiO}_{2}$ at $1900^{\circ} \mathrm{C}$

and $\mathrm{FeO}$ in the $\mathrm{SiO}_{2}-\mathrm{MgO}-\mathrm{FeO}$ ternary system.

(2) $\mathrm{Mg}^{2+}$ cations associate with silicate anions stronger than $\mathrm{Fe}^{2+}$ cations, therefore a random mixing does not occur in this system. When $y$ is a mole ratio of $\mathrm{Fe}_{2} \mathrm{SiO}_{4}$ and $\mathrm{Mg}_{2} \mathrm{SiO}_{4}, y$ may be assumed;

$$
\begin{aligned}
\frac{y}{1-y} & =\frac{\text { mole fraction of } \mathrm{Fe}_{2} \mathrm{SiO}_{4}}{\text { mole fraction of } \mathrm{Mg}_{2} \mathrm{SiO}_{4}} \\
& \approx \frac{K_{11} \text { of } \mathrm{MgO}-\mathrm{SiO}_{2} \text { system }}{K_{11} \text { of } \mathrm{FeO}-\mathrm{SiO}_{2} \text { system }}
\end{aligned}
$$

(3) The activity of $\mathrm{FeO}$ in the $\mathrm{FeO}-\mathrm{MgO}-\mathrm{SiO}_{2}$ ternary system is estimated from the following equation.

$$
a_{\mathrm{FeO}}=\gamma \cdot \mathcal{N}_{\mathrm{Fe}^{2+}}^{*} \cdot \mathcal{N}_{\mathrm{O}^{2-}}
$$

where $\gamma$ is an interaction coefficient between $\mathrm{FeO}$ and $\mathrm{MgO}$ in the $\mathrm{MgO}-\mathrm{FeO}$ binary system. (Actually an activity coefficient of $\mathrm{FeO}$ in the $\mathrm{FeO}-\mathrm{MgO}$ binary system will be used.)

$$
\mathcal{N}_{\mathrm{Fe}^{2+}}^{*}=\frac{\text { Ion fraction of "Free" } \mathrm{Fe}^{2+}}{\begin{array}{c}
\text { Ion fraction of "Free " } \mathrm{Fe}^{2+} \\
+ \text { Ion fraction of "Free" } \mathrm{Mg}^{2+}
\end{array}}
$$

"Free" means that the cations do not associate with silicate anions.

Now we show how to calculate the activity of FeO in the ternary system.

\section{(i) In high $\mathrm{SiO}_{2}$ regions}

All of $\mathrm{Mg}^{2+}$ cations may be combined with silicate anions, because of high concentration of $\mathrm{SiO}_{2}$.

$$
\text { "Free" } \mathcal{N}_{\mathrm{Mg}^{2+}} \approx 0, \text { then } \mathcal{N}_{\mathrm{Fe}^{2+}}^{*} \approx 1
$$

Also $\gamma=1$, because of no interaction between $\mathrm{Fe}^{2+}$ and $\mathrm{Mg}^{2+}$ cations.

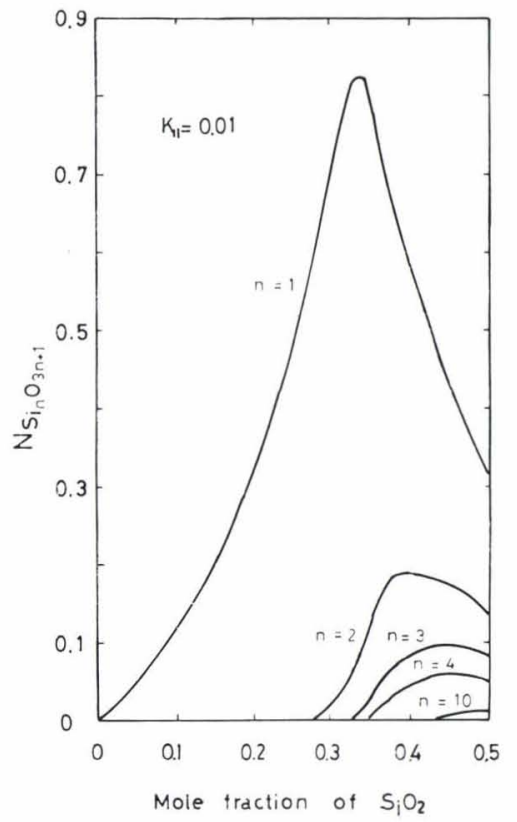

Fig. 5. Ion fractions of $\mathrm{SiO}_{4}{ }^{4-}, \mathrm{Si}_{2} \mathrm{O}_{7}{ }^{6-}, \mathrm{Si}_{3} \mathrm{O}_{10}{ }^{8-}, \mathrm{Si}_{4} \mathrm{O}_{13}{ }^{10-}$ and $\mathrm{Si}_{10} \mathrm{O}_{31}{ }^{22-}$ plotted against mole fraction of silica for the system $\mathrm{MgO}-\mathrm{SiO}_{2}$

Therefore,

$$
a_{\mathrm{FeO}}=\mathcal{N}_{\mathrm{O}^{2-}}
$$

$\mathcal{N}_{\mathrm{O}^{2-}}$ can be calculated from the polymer theory.

(ii) In low $\mathrm{SiO}_{2}$ regions

It will be assumed that $\mathcal{N}_{0}^{2-}$ is unity, because of low concentration of $\mathrm{SiO}_{2}$.

Therefore,

$$
a_{\mathrm{FeO}} \approx \gamma \mathcal{N}_{\mathrm{Fe}^{2+}}^{*+}
$$

Then $\mathcal{N}_{\mathrm{Fe}^{2+}}^{*}$ can be calculated from the following.

$$
\begin{aligned}
& \text { Ion fraction of " Free " } \mathrm{Fe}^{2+} \\
& \quad=\mathcal{N}_{\mathrm{FeO}}-\left(2 y \mathcal{N}_{1}+3 y \mathcal{N}_{2}+\ldots \ldots+(x+1) y \mathcal{N}_{x}\right) \\
& \quad=\mathcal{N}_{\mathrm{FeO}}-y \Sigma(x+1) \mathcal{N}_{x} \ldots \ldots \ldots \ldots \ldots \ldots \ldots \ldots \ldots \ldots \ldots \ldots \ldots \ldots \ldots \\
& \mathcal{N}_{\mathrm{SiO}_{2}}=\mathcal{N}_{1}+2 \mathcal{N}_{2}+\ldots \ldots+x \mathcal{N}_{x}=\Sigma x \cdot \mathcal{N}_{x} \ldots \ldots \ldots \ldots
\end{aligned}
$$

where $\mathcal{N}_{\mathrm{FeO}}$ and $\mathcal{N}_{\mathrm{SiO}_{2}}$ are mole fraction of $\mathrm{FeO}$ and $\mathrm{SiO}_{2}$, respectively.

$\mathcal{N}_{1}, \mathcal{N}_{2} \ldots \mathcal{N}_{x}$ are ion fraction of $\mathrm{SiO}_{4}{ }^{4-}, \mathrm{Si}_{2} \mathrm{O}_{7}{ }^{6-}$, $\mathrm{Si}_{x} \mathrm{O}_{3 x+1}{ }^{2(x+1)-}$, respectively.

From the polymer theory ${ }^{1)}$

$$
\frac{\Sigma x \mathcal{N}_{x}}{\Sigma \mathcal{N}_{x}}=\frac{1}{1-3 P_{\mathrm{AA}}}
$$

where $P_{\mathrm{AA}}$ is a probability to condense $\mathrm{SiO}^{-}$with $\mathrm{SiO}^{-}$, and can be calculated from the value of $K_{11}$ by the polymer theory. ${ }^{1)}$ Equation (12) is obtained from Eqs. (9) and (11).

Ion fraction of "Free" $\mathrm{Fe}^{2+}$

$$
\begin{aligned}
& =\mathcal{N}_{\mathrm{FeO}}-y \Sigma(x+1) \mathcal{N}_{x} \\
& =\mathcal{N}_{\mathrm{FeO}}-y\left[\mathcal{N}_{\mathrm{SiO}_{2}}+\left(1-3 P_{\mathrm{AA}}\right) \mathcal{N}_{\mathrm{SiO}_{2}}\right]
\end{aligned}
$$

Also

$$
\begin{aligned}
& \text { Iron fraction of "Free" } \mathrm{Mg}^{2+} \\
& \quad=\mathcal{N}_{\mathrm{MgO}}-(1+y)\left[\mathcal{N}_{\mathrm{SiO}_{2}}+\left(1-3 P_{\mathrm{AA}}\right) \mathcal{N}_{\mathrm{SiO}_{2}}\right]
\end{aligned}
$$


Therefore

$$
\mathcal{N}_{\mathrm{Fe}^{2+}}^{*}=\frac{[c /(1+c)] \cdot\left(1-\mathcal{N}_{\mathrm{SiO}_{2}}\right)-y\left[\mathcal{N}_{\mathrm{SiO}_{2}}+\left(1-3 P_{\mathrm{AA}}\right) \mathcal{N}_{\mathrm{SiO}_{2}}\right]}{1-2 \mathcal{N}_{\mathrm{SiO}_{2}}-\left(1-3 P_{\mathrm{AA}}\right) \mathcal{N}_{\mathrm{SiO}_{2}}}
$$

where

$$
C=\mathcal{N}_{\mathrm{FeO}} / \mathcal{N}_{\mathrm{MgO}}
$$

Figure 6 shows the theoretical curves from Eqs. (7) and (8), compared with the experimental data.

\section{Conclusion}

The activity of $\mathrm{FeO}$ was measured in $\mathrm{FeO}-\mathrm{MgO}$ $\mathrm{SiO}_{2}$ ternary system by using the levitation method.

From the activity of $\mathrm{FeO}$, the activity of $\mathrm{MgO}$ $\mathrm{SiO}_{2}$ system was calculated. This activity line fits the theoretical curve from the polymer theory when the equilibrium constant of the polymer theory $\left(K_{11}\right)$ is 0.01 .

Application of the polymer theory to the ternary system $\mathrm{MgO}-\mathrm{SiO}_{2}-\mathrm{FeO}$ seems to be possible with several assumptions.

\section{Acknowledgements}

This work was done at the Atlantic Regional Laboratory, National Research Council of Canada. One of the authors (M.S.) wishes to express his gratitude to NRCC for the Fellowship.

The authors wish to thank Mr. G. Caines and Mr. J. Uher for chemical analysis of the samples.

\section{REFERENCES}

1) S. G. Whiteway, I. B. Smith and C. R. Masson: Can. J. Chem., 48 (1970), 33.

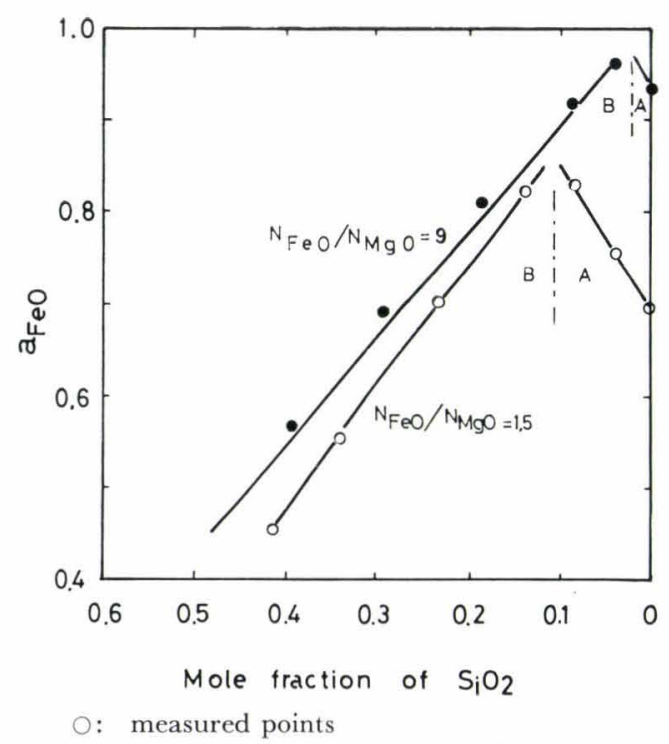

In the $\mathrm{A}$ regions, lines corresponds to $a_{\mathrm{FeO}}=\gamma_{\mathrm{Fe}}{ }^{2+}$. In the $\mathrm{B}$ regions, lines correspond to $a_{\mathrm{FeO}}=\mathcal{N}_{\mathrm{O}^{2-}}$.

Fig. 6. Application of the polymer theory to the ternary system $\mathrm{MgO}-\mathrm{SiO}_{2}-\mathrm{FeO}$ at $1900^{\circ} \mathrm{C}$

2) C. R. Masson, I. B. Smith and S. G. Whiteway: Can. J. Chem., 48 (1970), 1456.

3) P. A. Distin, S. G. Whiteway and C. R. Masson: Can. Met. Q., 10 (1971), 13.

4) L. S. Darken: Trans, AIME, 239 (1967), 80.

5) L. S. Darken: J. Amer. Chem. Soc., 72 (1950), 2909.

6) L. S. Darken and R.W. Gurry: Physical Chemistry of Metals, McGrow-Hill Co., New York, (1963), 340.

7) J. F. Elliott and M. Gleiser: Thermochemistry for Steelmaking II, Addison-Wesler Publ. Co., London, (1963), 575. 